\begin{tabular}{|c|c|c|}
\hline JURNAL & ISSN: 2502-6496 (Print) \\
\hline $\begin{array}{c}\text { Volume 1, Nomor 2, p 73-82 } \\
\text { Oktober 2017 }\end{array}$ & http://zona.pelantarpress.co.id/ \\
\hline
\end{tabular}

\title{
Strategi pengembangan ekowisata pegunungan di Kabupaten Natuna Provinsi Kepulauan Riau
}

\author{
Said Muhammad Qadry ${ }^{1}$, Zulfan Saam ${ }^{2}$, Dessy Yoswaty ${ }^{3}$ \\ ${ }^{1}$ Alumni Pascasarjana Ilmu Lingkungan Program Pascasarjana Universitas Riau. \\ ${ }^{2}$ Pascasarjana Ilmu Lingkungan Program Pascasarjana Universitas Riau. \\ ${ }^{3}$ Fakultas Perikanan dan Ilmu Kelautan Universitas Riau.
}

\begin{abstract}
This research aims to analyze the tourist attractions, amenitas and accessibility assuport ecotourism mountains on Mount Ranai as well as reviewing and formulating development strategies of ecotourism in mountainous area of Mount Ranai. Data retrieval is done by survey method with descriptive qualitative analysis and SWOT analysis. The results of this study indicate the condition of the Attractions found in the region of Mount Ranai is very diverse and is unique so it is potentially exploited as tourist attractions. While amenitas and accessibility is already quite sufficient to support the development of ecotourism mountains. Government's role is indispensable in the development of ecotourism is mountainous area of Mount Ranai. As for the effort that should involve the parties such as related organizations pertaining to the environment and related agencies. On the other hand, the efforts of the utilization potential of natural resources in a friendly with the concept of ecotourism was necessary in an effort to maintain the raw water source of the local community.
\end{abstract}

Keywords: Ecotourism; mount; natuna

Di ujung utara Indonesia, terdapat salah satu kabupaten yang terkenal dengan keanekaragaman sumber daya alamnya yaitu Kabupaten Natuna yang terletak di Provinsi Kepulauan Riau. Menurut Riswandi (2013), sektor andalan Kabupaten Natuna saat ini adalah sumber daya alam minyak bumi dan gas bumi (migas). Namun harus disadari bahwa pemanfaatan sumber daya alam migas itu tidak bisa terus menerus diandalkan. Sumber daya alam migas akan habis pada batas waktu tertentu dan tidak dapat diperbaharui, maka diharapkan sumber daya alam selain sektor migas menjadi alternatif sebagai salah satu sumber Pendapatan Asli Daerah (PAD) dan menjadi sektor yang dapat memberikan kontribusi terhadap kemajuan ekonomi, penciptaan lapangan pekerjaan, dan pengurangan kemiskinan.

Salah satu bentuk pemanfaatan Sumber Daya Alam (SDA) non migas yang terdapat di Kabupaten Natuna adalah sektor pariwisata alam. Saat ini, Kabupaten Bintan, Kota Tanjungpinang dan Kota Batam telah menjadi destinasi wisata yang sangat dikenal oleh wisatawan lokal, dalam negeri maupun wisatawan mancanegara. Aksesibilitas yang baik dan letak daerah yang strategis mnejadikan Kabupaten Bintan, Kota Tanjungpinang dan Kota Batam berkembang dengan pesat. Peningkatan jumlah wisatawan asing ke Provinsi Kepulauan Riau terlihat meningkat pada tahun 2013 tercatat jumlah wisatawan asing sebanyak 1.859 .066 orang yang sebelumnya pada tahun 2012 hanya 1.767 .439 orang. Kenaikan yang terjadi sebanyak 5,18\%. (BPS Kepri, 2014).

Selain 3 (tiga) daerah tersebut, Kabupaten Natuna juga memiliki potensi wisata alam yang jika dikelola secara baik maka akan memiliki daya tarik tersendiri dibandingkan daerah lainnya. Hal ini dikarenakan, ada banyak atraksi yang bisa diangkat sebagai objek wisata baik itu wisata bahari, wisata pegunungan, wisata daerah terpencil (primitive area) serta wisata flora dan fauna. Saat ini, wisata yang sudah terkelola baru sebatas wisata bahari saja. Pada saat ini, khususnya potensi wisata pegunungan belum dikelola secara baik. Hal ini terlihat dengan adanya kerusakan lingkungan gunung akibat ulah oknumoknum yang dilakukan secara sengaja maupun tanpa sengaja. Disamping itu, kurangnya pengetahuan masyarakat terkait pentingya kelestarian Sumber Daya Alam untuk menjaga ekosistem gunung juga turut andil dalam kerusakan tersebut.

Oleh karena pentingnya menjaga ekosistem pegunungan terutama gunung Ranai tersebut, maka perlu dilakukannya kajian dan perumusan strategi dalam pengelolaan potensi yang ada di pegunungan terutama Gunung Ranai. Diharapkan penelitian ini mampu meningkatkan pendapatan daerah serta terciptanya keseimbangan ekosistem melalui konsep eksploitasi potensi yang ada secara konservatif dan berkelanjutan. 
Penelitian ini bertujuan untuk menganalisa atraksi wisata, amenitas dan aksesibilitas sebagai penunjang ekowisata pegunungan di gunung Ranai serta mengkaji dan merumuskan strategi pengembangan ekowisata pegunungan di kawasan gunung Ranai.

\section{METODE PENELITIAN}

Penelitian ini dilaksanakan pada bulan Juli 2015 dan dilakukan di Kawasan Gunung Ranai, Kabupaten Natuna Provinsi Kepulauan Riau. Lokasi ini ditetapkan berdasarkan pertimbangan peneliti atas dasar keberagaman potensi atraksi wisata yang terdapat di kawasan tersebut sehingga efektifitas lokasi akan mendukung hasil yang ingin. Teknik pengumpulan data dilakukan dengan metode survey serta wawancara dan penyebaran kuisioner untuk mendapatkan data primer, sedangkan data sekunder berasal dari Dinas Pariwisata Kabupaten Natuna, studi pustaka dan literatur yang terkait.

Tahapan pertama dalam penelitian ini adalah mengumpulkan data primer yang diperoleh melalui wawancara mendalam (Indepth Interview) dengan fokus pertanyaan pada tujuan studi terhadap para informan/narasumber yang dinyatakan tergolong dalam kriteria yang telah ditentukan. Selanjutnya peneliti melakukan wawancara dengan menggunakan kuesioner kepada para wisatawan guna mengetahui penilaian wisatawan terkait potensi atraksi wisata, amenitas dan aksesibilitas yang ada di kawsan gunung Ranai dengan pertanyaan tertutup. Selain itu, peneliti juga melakukan teknik observasi langsung (diret Observation) pada lokasi studi guna melihat secara seksama kondisi dilapangan guna memperoleh data tentang potensi pengembangan melalui variabel yang telah ditetapkan.

Selain data primer, peneliti juga memerlukan data sekunder yang diperoleh dari organisasi atau instansi terkait dengan kebutuhan data dilapangan. Sedangkan menurut waktu pengumpulannya, data yang dikumpulkan adalah data cross section yaitu data kondisi eksisting lokasi studi guna menggambarkan keadaan untuk menjadi pertimbangan dalam tahap analisis. Berdasarkan sifatnya, data yang dikumpulkan adalah data kualitatif.

Pada tahap analisa, ditentukan beberapa unsur dan variabel yang berkaitan dengan ekowisata. Unsur dan variabel ini bertujuan mempermudah peneliti dalam mengidentifikasi potensi dan kelayakan suatu kawasan untuk dikembangkan sebagai kawasan ekowisata.

Tabel 1. Unsur dan Variabel Ekowisata

\begin{tabular}{|c|c|}
\hline Unsur & 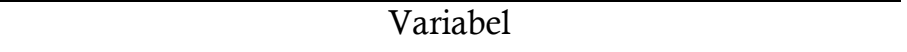 \\
\hline Keaslian dan kealamian & Kondisi ekosistem \\
\hline Keunikan & Keberadaan biota yang menjadi ciri khas \\
\hline Kawasan Jelajah & Wilayah jelajah \\
\hline Bentang alam/landscape & Panorama alam \\
\hline Kenyamanan & Kenyamanan alami \\
\hline Sumber daya manusia & Petugas lapangan \\
\hline Komitmen Pemerintah & Program Pengembangan \\
\hline Aksesibilitas & Jalan, jarak tempuh, moda transportasi \\
\hline Sumber air & Ketersediaan \\
\hline \multicolumn{2}{|l|}{$\begin{array}{ll}\text { dan aksesibilitas sebagai penunjan } \\
\text { 1. } & \text { Variabel atraksi wisata u } \\
& \text { terhadap beberapa unsur die } \\
\text { - } & \text { Keaslian dan kealamian } \\
\text { - } & \text { Keunikan } \\
\text { - } & \text { Kawasan jelajah } \\
\text { - } & \text { Bentang Alam / Landscape } \\
\text { - } & \text { Kenyamanan } \\
\text { - } & \text { Sumber air. }\end{array}$} \\
\hline
\end{tabular}


2. Variabel penilaian Kondisi Amenitas wisata untuk ekowisata pegunungan di kawasan gunung Ranai secara keseluruhan dapat dilihat dari indikator dan pemberian range score sebagai berikut :

Buruk : Apabila pada atraksi wisata tidak atau kurang memiliki fasilitas pendukung.

Cukup : Apabila memiliki cukup fasilitas dengan kondisi baik.

Baik : Apabila memiliki fasilitas yang lengkap dan memenuhi kebutuhan.

Penting untuk diingat bahwa fasilitas pendukung wisata pada umumnya dengan ekowisata memiliki perbedaan yang signifikan dikarenakan ekowisata merupakan wisata non-masal dan mengutamakan keberlangsungan ekosistem alam yang ada pada kawasan wisata tersebut. Selain faktor keberadaan fasilitas pendukung, faktor lain yang juga berkaitan erat dengan keberadaan amenitas adalah komitmen pemerintah dan keberadaan sumber daya manusia.

3. Variabel penilaian Kondisi Aksesibilitas menuju kawasan ekowisata pegunungan di gunung Ranai tersebut dapat dilihat dari indikator sebagai berikut:

a) Bagaimana Kondisi Infrastruktur Jalan?

Buruk : apabila tidak memiliki akses jalan atau kondisi jalan yang buruk.

Cukup: apabila memiliki jalan yang memadai menuju obyek wisata.

Baik : apabila memiliki kondisi jalan yang baik

b) Bagaimana kondisi letak lokasi?

Buruk : apabila letak lokasi jauh dari moda transportasi utama (bandara, pelabuhan, terminal) $>75 \mathrm{~km}$.

Cukup: apabila letak lokasi cukup mudah dijangkau $25-75 \mathrm{~km}$.

Baik : apabila lokasi atraksi wisata sangat mudah dijangkau $<25 \mathrm{~km}$.

c) Bagaimana kondisi moda transportasi udara, laut, darat menuju ke lokasi atraksi wisata.

Buruk : apabila tidak tersedia angkutan umum/sewaan yang standby di lokasi ruang publik seperti terminal, pelabuhan laut atau bandara untuk mengantarkan wisatawan ke destinasi wisata.

Cukup : apabila tersedia angkutan umum/sewaan yang standby di lokasi ruang publik seperti terminal, pelabuhan laut atau bandara yang siap mengantarkan wisatawan ke destinasi wisata.

Baik : apabila tersedia angkutan umum/sewaan yang standby sepanjang waktu di lokasi ruang publik seperti terminal, pelabuhan laut atau bandara yang siap mengantarkan wisatawan ke destinasi wisata dan kondisi moda transportasi tersebut layak dan nyaman bagi wisatawan.

Untuk menjawab tujuan kedua, dilakukan dengan analisis SWOT. Dalam hal strategi pengembangan Ekowisata, analisis SWOT dapat diartikan sebagai metode perencanaan strategis yang digunakan untuk mengevaluasi kekuatan (strength), kelemahan (weakness), peluang (opportunities) dan ancaman (threats). Proses ini melibatkan tujuan yang spesifik dari suatu kegiatan dan mengidentifikasi faktor eksternal dan internal yang mendukung dan yang tidak dalam mencapai tujuan tersebut. Analisis SWOT dapat diterapkan dengan cara menganalisis dan memilah berbagai hal yang mempengaruhi keempat faktornya, kemudian menggambarkan dalam matriks SWOT.

\section{HASIL DAN PEMBAHASAN}

\section{Kondisi Fisik dan Topografi Gunung Ranai}

Gunung Ranai merupakan gunung dataran rendah, sebab ketinggiannya berkisar antara $300 \mathrm{~s} / \mathrm{d}$ 1.035 meter di atas permukaan laut (dpl). Bagi mereka pelancong yang sudah pernah mendaki gunung ini, mengatakan bahwa Gunung Ranai sangatlah unik. Dikatakan unik karena di gunung ini banyak ditemukan jenis pepohonan langka dan tidak umum tumbuh di dataran ketinggian standarnya.

Fenomena menarik yang ditemui oleh pendaki, yaitu gradasi jenis-jenis tanaman yang terdapat di gunung ini. Pada ketinggian tertentu, para pendaki akan menemukan tipe-tipe vegetasi yang memperlihatkan ciri khas pegunungan dataran atas yang biasanya tumbuh pada gunung di ketinggian 2.000 meter. Pada ketinggian 800 meter dpl, hutan di Gunung Ranai masih dominan ditumbuhi oleh jenisjenis tanaman seperti meranti (dipterocarpaceae), rasamala (altingia excelsa), keruing (dipterocarpus spp) dan turi (quercus spp). Sedangkan di atas ketinggian itu, tampak perubahan tipe vegatasi, yaitu perubahan dari tipe hutan dataran rendah ke tipe kawasan hutan dataran atas. Hal ini terlihat misalnya dari tumbuhtumbuhan yang didominasi oleh semak, belukar, dan pohon-pohon dengan ukuran pendek seperti 
umumnya pada hutan dataran atas. Fenomena alam ini biasa disebut sebagai hutan berawan dataran rendah (Lowland Cloud Forest).

Hutan berawan (Cloud Forest) umumnya terjadi di wilayah pegunungan yang terdapat di pulau besar serta jauh dari pantai, atau bisa juga terjadi pada pegunungan di wilayah pulau yang kecil serta dekat dengan pantai. Tipe hutan seperti ini sebagian wilayahnya sering diselimuti oleh kabut, sehingga memungkinkan tipe-tipe vegetasi tertentu dapat tumbuh di kawasan gunung tersebut.

Untuk mencapai puncak Gunung Ranai, para pendaki harus melampaui tiga puncak berupa tebing batu dengan ketinggian yang berbeda-beda. Puncak pertama bernama Puncak Serendit dengan ketinggian 968 meter. Puncak ini merupakan gugusan tebing dengan tinggi mencapai 100 meter. Puncak selanjutnya adalah Puncak Erik Samali yang berada pada ketinggian 999 meter dpl. Puncak ini merupakan tebing kedua dengan tinggi tebing sekitar 150 meter. Sementara puncak ketiga (puncak tertinggi) bernama Puncak Datuk Panglima Husin, terletak pada ketinggian 1.035 meter. Seperti dua puncak sebelumnya, Puncak Datuk Panglima Husin juga merupakan tebing dengan ketinggian kira-kira 200 meter.

\section{Potensi Ekowisata}

Dalam merencakan dan menjadikan suatu kawasan sebagai kawasan yang memiliki fungsi khusus, keberadaan variabel-variabel pendukung sangatlah penting agar tercapainya tujuan yang diinginkan dan fungsi kawasan terwujud secara tepat sesuai dengan kondisi eksisting yang ada. Begitu juga untuk merencanakan suatu gunung sebagai kawasan ekowisata yang dalam hal ini diukur pada 3 hal yaitu Atraksi, Amenitas dan Aksesibilitas. Berikut adalah ulasan terkait 3 hal tersebut yang terdapat di kawasan Gunung Ranai.

\section{A. Atraksi}

Menurut Fandeli (2003), atraksi adalah seluruh objek yang menjadi daya tarik wisata. Sama halnya dengan gunung pada umumnya, kawasan gunung Ranai juga menyajikan beberapa atraksi yang berpotensi utuk dikembangkan sebagai objek daya tarik wisata. Berikut adalah beberapa potensi atraksi yang bisa dikembangkan sebagai objek wisata di kawasan Gunung Ranai.

\section{Bentang Alam}

Gunung Ranai memiliki bentang alam yang indah. Dari puncak, akan terlihat pemandangan perkotaan Ranai yang terletak di tepi laut. Selain itu, lebatnya hutan yang masih tergolong asri juga terlihat dari puncak gunung Ranai. Pada pagi hari, pendaki bisa melihat matahari terbit (sunrise) dengan laut Cina Selatan sebagai latarnya dan juga bisa melihat matahari terbenam (sunset)pada sore harinya.

\section{- $\quad$ Air Terjun}

Seperti halnya kawasan gunung pada umumnya, di gunung Ranai juga terdapat air terjun yang juga menjadi salah satu daya tarik di kawasan gunung tersebut. Berdasarkan masyarakat tempatan, ditemukan 2 (dua) lokasi air terjun alami, namun hanya 1 (satu) lokasi saja yang bisa diakses dengan baik dan telah biasa dikunjungi para wisatawan. Namun ketika musim kemarau, debit airnya akan sangat berkurang. Adapun ketinggiannya mencapai 15 meter.

Untuk saat ini sudah ada fasilitas yang dibuat oleh dinas terkait berupa 2 buah gazebo dan tempat sampah. Namun kondisi fasilitas tersebut sangat tidak terawat.

\section{- $\quad$ Flora dan Fauna}

Untuk flora di gunung Ranai sangat beragam. Pada ketinggian hingga 800 mdpl, dominan ditumbuhi oleh jenis-jenis tumbuhan seperti meranti, rasamala, keruing, rotan dan turi. Di atas ketinggian tersebut, tampak perubahan tipe vegatasi, yaitu perubahan dari tipe hutan dataran rendah ke tipe kawasan hutan dataran tinggi. Hal ini terlihat misalnya dari tumbuh-tumbuhan yang didominasi oleh semak, belukar, dan pohon-pohon dengan ukuran pendek seperti umumnya pada hutan dataran atas. Bahkan akan sangat mudah menemukan berbagai jenis jamur dan lumut yang menempel pada batu-batuan hingga pada pohon layaknya hutan di daratan tinggi dengan ketinggian diatas $2000 \mathrm{mdpl}$.

Fauna di gunung Ranai juga terbilang memiliki keberagaman yang tinggi hingga terdapat fauna yang endemik. Adapun jenis fauna yang ada di gunung Ranai diantaranya berbagai jenis burung, mamalia dan herpetofauna (hewan melata). Untuk burung, berdasarkan data dari Dinas Kehutanan Kabupaten Natuna, tercatat ada 43 jenis burung yang terdiri dari 9 ordo dan 21 famili. Diantara burung tersebut, terdapat 3 jenis yang termasuk dalam kategori Appendix II CITES (akan menjadi terancam punah) yakni Pernis ptilorhynchus (Sikep madu Asia), Haliaeetus leucogaster (Elang laut perut putih) dan Anthracoceros albirostris (Kangkareng perut putih).

Untuk mamalia, terdapat 25 jenis yang berhasil dicatat pada tahun 2011. Jumlah spesies terbanyak adalah kelompok Chiroptera/kelelawar yang terdiri dari 15 jenis meliputi 6 suku. Kemudian diikuti oleh 
Rodensia/pengerat dengan 6 jenis meliputi 2 suku, primata 2 jenis terdiri dari 1 suku, kemudian karnivora dan dermoptera masing-masing 1 jenis. Dari sekian daftar mamalia tersebut, terdapat 1 jenis hewan yang dilindungi yaitu Tando (Galeopterus variegatus). 4 jenis masuk dalam kategori CITES Appendix 2 yaitu kalong kecil (Pteropus hypomelanus), jelarang/tupai raya (Ratufa affinis), monyet ekor panjang (Macaca Fascicularis) dan Kekah (Presbytis natunae) yang saat ini banyak diburu oleh masyarakat tempatan dan pendatang.

Berdasarkan kriteria IUCN, jelarang /tupai raya masuk dalam kategori near threatened/nyaris terancam, kekah masuk dalam kategori vulnerable/rawan dan endemik atau hanya terdapat di pulau Bunguran. Sedangkan sisanya masuk dalam kategori resiko rendah/least concern.

Untuk herpetofauna tercatat sebanyak 43 jenis yang terdiri dari 14 jenis katak, 10 jenis bunglon/londok, 3 jenis cicak, 4 jenis kadal, 7 jenis ular, 3 jenis kura-kura, 1 jenis labi-labi, dan 1 jenis biawak. Berdasarkan penelitian yang dilakukan oleh Awal Rianto (2011), terdapat spesimen yang diduga sebagai jenis baru yaitu dari katak marga asnonia dan cicak marga Cyrtodactylus.

Menurut Maharadatunkamsi (2008), keanekaragaman jenis mamalia di Natuna dapat dikembangkan menjadi paket ekowisata dan usaha penangkaran untuk perdagangan hewan mamalia yang berpotensi secara komersil. Hal ini dapat menghasilkan pemasukan baik bagi pemerintah maupun masyarakat. Hal ini juga didukung dalam Peraturan Pemerintah No. 8 tahun 1999 tentang Pemanfaatan Tumbuhan dan Satwa Liar. Selain itu, aturan terkait penangkapan juga telah diatur dalam Keputusan Menteri Kehutanan No. 447/Kpts-II/2003 tentang Tata Usaha Pengambilan atau Penangkapan dan Peredaran Tumbuhan dan Satwa Liar.

\section{Wisata Petualangan}

Bagi pecinta wisata petualangan, kawasan gunung Ranai juga memiliki potensi tersebut terutama untuk wisata kegiatan alam bebas, lintas alam dan juga pendakian tentunya.Untuk kegiatan petualangan ini, juga telah tersedia Pusat Pendidikan dan Latihan milik TNI AD yang juga bisa digunakan oleh masyarakat melalui izin dan kerjasama dengan pihak TNI AD di Kabupaten Natuna. Selain itu, untuk menunjang keselamatan para pendaki, pendaki bisa menggunakan radio HT (handy talkie) yang dipinjamkan oleh aparat penjaga pos yang terdapat di pintu pendakian. Pos jaga juga telah menyediakan repeater sehingga komunikasi dari pos kepada para pendaki bisa terus dilakukan secara baik guna menunjang keselamatan para pendaki dan mempercepat proses darurat /emergency. Selain fasilitas komunikasi dan Pusdiklat, jalur untuk pendakian dan lintas alam juga telah tersedia berupa jalan setapak dan diberi tanda-tanda (navigasi) agar pendaki tidak tersesat.

Terkait atraksi-atraksi yang ada di kawasan Gunung Ranai tersebut, peneliti memperoleh tanggapan dari responden melalui kuesioner terkait beberapa unsur penting dalam ekowisata diantaranya sebagai berikut :

\section{a. Kealamian}

Mayoritas responden menyatakan bahwa kawasan Gunung Ranai masih alami yakni sebanyak $91 \%$. Kealamian tersebut termasuk pada setiap objek wisata yang menjadi atraksi di kawasan Gunung Ranai yang memang masih sangat terjaga. Berdasarkan hasil wawancara terhadap salah satu pejabat di lingkungan Dinas Pariwisata Natuna yaitu Bapak Marhafiz Luthfi, kawasan Gunung Ranai memang belum terlalu tersentuh oleh pembangunan. Hal ini dikarenakan kawasan tersebut sudah ditetapkan sebagai kawasan lindung sehingga keberadaan ekosistemnya masih sangat terjaga. Bahkan untuk pembangunan yang mendukung fungsi wisata masal pada umumnya juga sulit dilakukan karena status kawasan tersebut. Oleh sebab itu, pemanfaatan kawasan Gunung Ranai dengan konsep ekowisata sangat layak untuk diterapkan karena tidak bertentangan dengan peraturan terkait kawasan lindung.

\section{b. Keunikan}

Untuk tingkat keunikan, 66\% responden menjawab kawasan Gunung ranai memang tergolong unik. Hal ini dikarenakan terdapat beberapa satwa langka yang menjadi penghuni kawasan ini diantaranya yang cukup dikenal yaitu Kekah Natuna (Presbytis natunae). Selain itu, keunikan lainnya adalah hutan di Gunung Ranai tergolong hutan berawan dataran rendah (Lowland Cloud Forest). Hal ini memungkinkan tumbuhnya vegetasi-vegetasi tertentu yang biasanya tumbuh pada hutan di gunung dengan ketinggian 2000 mdpl.

\section{c. Kawasan Jelajah}

Kawasan jelajah untuk menikmati atraksi di Gunung Ranai tergolong pendek dan sangat memadai jika dibandingkan dengan daerah-daerah gunung lainnya. Selain rute-rute yang sudah disiapkan berupa jalan setapak, tanda-tanda yang dibuat sebagai navigasi bagi para wisatawan juga telah tersedia walaupun baru sekedar ikatan pita merah pada pohon. Namun hal ini sangat membantu agar wisatawan tidak 
tersesat. selain itu, Gunung Ranai yang tidak terlalu tinggi menjadikan pendakian tidak terlalu lama. Untuk tiba dipuncak biasanya hanya membutuhkan waktu sekitar 4 jam. Namun jika wisatawan menuju ke objek air terjun hanya diperlukan waktu sekitar 1 jam perjalanan.

\section{d. Bentang Alam}

Untuk keindahan bentang alam dan panorama di kawasan Gunung ranai, 94\% responden menjawab "Ya". Dari puncak Gunung Ranai, akan terlihat Kota Ranai secara keseluruhan yang memanjang mengikuti garis pantai. Selain itu, bentangan hutan hujan yang hijau dan asri akan menyejukkan pandangan anda terutama pada pagi hari. Jika berada dipuncak pada pagi hari, kita akan bisa melihat matahari terbit (Sunrise) dari arah laut Cina Selatan. Sedangkan pada sore harinya, kita juga bisa menyaksikan matahari terbenam (Sunset).

\section{e. Kenyamanan Alami}

Untuk tingkat kenyaman secara alami yang dirasakan pengunjung ketika berkunjung ke kawasan Gunung Ranai, 98\% responden menjawab "Ya". Hal ini sudah jelas, kondisi objek wisata yang masih sangat alami akan memberikan nuansa yang nyaman bagi para pengunjung yang memang tidak akan bisa didapatkan di kawasan perkotaan. Dengan adanya vegetasi-vegetasi yang hijau, satwa-satwa yang bebas bergerak didalam ekosistem alaminya yang memang tidak terlalu sulit ditemukan di kawasan ini akan memberikan hiburan tersendiri bagi para wisatawan yang datang.

\section{f. Sumber Air}

Untuk menikmati atraksi yang ada di kawasan Gunung ranai, pengunjung akan memerlukan tenaga yang ekstra sehingga keberadaan sumber air untuk melepas dahaga dan keperluan lainnya sangat penting. Dari segi kualitas dan kuantitas air itu sendiri, $87 \%$ responden menyatakan sudah sangat memadai. Dari segi kualitas, air yang tersedia memang bisa langsung diminum oleh wisatawan. Airnya memang bening, tidak berbau dan sangat menyegarkan. Sedangkan untuk kuantitas memang sangat melimpah. Selain itu, untuk kawasan Gunung ranai terdapat 2 titik sumber air yaitu air terjun yang terdapat pada ketinggian \pm 200 mdpl dan air yang muncul dari celah-celah batu pada ketinggian \pm 900 mdpl yang biasanya menjadi lokasi persinggahan bagi para pendaki yang ingin mendaki hingga puncak dan bermalam disana

\section{B. Amenitas}

Amenitas merupakan fasilitas yang harus disediakan agar wisatawan dapat memperoleh kepuasan dalam berwisata termasuk peralatan yang mempermudah wisatawan dalam memperoleh informasi tentang obyek wisata atau event pariwisata yang sedang dipergelarkan. Dalam hal ini, fasilitas untuk mendukung ekowisata tentu berbeda dengan wisata pada umumnya sebab ekowisata merupakan lawan dari wisata masal.

Berdasarkan hasil kuesioner yang ditujukan pada responden, hanya $28 \%$ yang menyatakan fasilitas pendukung tersebut dalam keadaan baik. Sedangkan yang menyatakan "cukup" sebanyak $24 \%$. Sisanya 48\% menyatakan "buruk". Hal ini memang terlihat dari kondisi fasilitas yang ada sangat kurang diperhatikan oleh pihak terkait sehingga sangat tidak terawat.Namun untuk para pendaki yang ingin mencapai puncak gunung, sudah terdapat fasilitas radio HT (handy Talkie) dengan repeater yang tersedia di pos penjagaan. Hal ini memudahkan para pendaki untuk tetap terus bisa berkomunikasi dengan penjaga di pos jaga sehingga memungkinkan untuk tindakan darurat secara cepat jika terjadi sesuatu hal yang buruk.

Faktor lain yang juga terkait dengan keberadaan amenitas tersebut adalah komitmen pemerintah dan keberadaan sumber daya manusia.

\section{a. Komitmen Pemerintah}

Berdasarkan Rencana Induk Pengembangan Pariwisata Daerah (RIPPDA) Kabupaten Natuna Tahun 2010-2030, pemerintah telah menunjukkan komitmennya untuk memanfaatkan potensi yang ada di kawasan Gunung Ranai sebagai salah satu destinasi wisata di Natuna. Namun saat ini pemerintah masih memprioritaskan wisata bahari.

\section{b. Sumber Daya Manusia}

Sumber daya manusia merupakan variabel yang sangat penting baik dari segi kualitas maupun kuantitas. Untuk saat ini, dari pihak pemerintah memang belum menyediakan tenaga-tenaga terampil yang siap menjadi pemandu wisata di Kawasan Gunung Ranai. Namun saat ini telah berdiri beberapa organisasi dan LSM yang siap sedia untuk membantu para wisatawan untuk menikmati wisata yang ada di kawasan Gunung Ranai seperti Tim Rescue Natuna, Mapala STAI Natuna, Ikatan Pecinta Alam Natuna (IPANA) dan Radio Antar Penduduk Indonesia (RAPI) Kabupaten Natuna. 


\section{Aksesibilitas}

Aksesibilitas dalam hal wisata adalah kemudahan para wisatawan dalam mengakses menuju ke lokasi wisata termasuk ketersediaan moda transportasi dan infrastrukturnya. Bagi wisatawan, kemudahan akses untuk menuju ke lokasi wisata sangat penting dan sangat mempengaruhi minat para wisatawan tersebut.

Untuk wisatawan dari luar daerah Natuna yang ingin menikmati objek wisata di Kawasan Gunung Ranai, saat ini bisa melalui 2 jalur yaitu jalur laut dan jalur udara agar bisa menuju ke Kabupaten Natuna mengingat letak geografis Natuna yang merupakan daerah kepulauan. Untuk penggunaan jalur laut saat ini di Kabupaten Natuna telah dilayari kapal-kapal melayani rute ke Ibukota Provinsi yakni Kota Tanjung pinang dan rute menuju ke pulau Kalimantan seperti KM. Sabuk Nusantara 29 dan KM. Sabuk Nusantara 30 serta kapal perintis lainnya seperti KM. Trigas. Sedangkan untuk ke daerah yang lebih jauh terutama didaerah pulau jawa, telah tersedia kapal KM. Bukit Raya dan KM. Lawit yang merupakan armada kapal milik PT. Pelayaran Nasional Indonesia (PELNI) yang juga akan singgah di pelabuhan Kijang Kabupaten Bintan, Kepulauan Riau.

Untuk jalur udara, sarana angkutan udara di Kabupaten Natuna terdapat sebuah bandara yang di jelajahi oleh penerbangan komersial, yaitu Bandara Ranai di Ranai Ibukota Kabupaten Natuna. Untuk mencapai ibukota Kabupaten Natuna (Ranai) dari bandara Hang Nadim di Batam memakan waktu selama lebih 1 jam dengan pesawat bermesin Jet dan 1 jam 15 menit untuk pesawat jenis propeller (balingbaling). Pada saat ini hanya terdapat 2 (dua) maskapai saja yang masih tetap melayani rute penerbangan ke Natuna yaitu maskapai Wings Air yang merupakan salah satu grup dari Lion Air dan maskapai Sriwijaya Air. Adapun jadwal penerbangan yaitu 4 kali dalam seminggu dengan waktu hanya 1 kali penerbangan dalam sehari pada masing-masing maskapai.

Adapun jarak bandara menuju pusat kota Ranai (Ibukota Kabupaten Natuna) yakni hanya berjarak kurang dari $3 \mathrm{Km}$. Sedangkan untuk menuju ke kawsan Gunung Ranai hanya memerlukan waktu 10 menit dari pusat kota. Moda angkutan darat yang tersedia saat ini adalah ojek motor dan mobil angkutan umum yang siap mengantarkan para wisatawan menuju lokasi yang diinginkan.

Terkait aksesibilitas tersebut, ada 3 indikator penting yang menjadi tolak ukur dalam menentukan tingkat kepuasan seseorang terhadap aksesibilitas yaitu keberadaan infrastruktur, jarak jangkauan dan moda transportasi. Adapun penilaian yang dilakukan oleh responden melalui kuesioner dapat disimpulkan bahwa aksesibilitas menuju ke kawasan Gunung ranai sudah sangat memadai. Hanya saja pada moda transportasi dalam kota, saat ini belum terdapat moda trasportasi khusus menuju ke kawasan Gunung Ranai atau angkutan kota reguler seperti daerah lain. Yang ada hanya ojek dan angkutan untuk jarak jauh serta angkutan dengan jasa mobil rental. Meskipun demikian, karena jarak yang tidak terlalu jauh maka moda transportasi yang ada juga dirasakan cukup.

Secara umum, berdasarkan Teori siklus hidup destinasi pariwisata dikemukakan oleh Butler (1980) yang lebih dikenal dengan destination area lifecycle, dapat disimpulkan bahwa kawasan Gunung Ranai berada pada tahap Penemuan (exploration). Pada tahap ini Potensi pariwisata berada pada tahapan identifikasi dan menunjukkan destinasi memiliki potensi untuk dikembangkan menjadi daya tarik atau destinasi wisata karena didukung oleh keindahan alam yang masih alami, daya tarik wisata alamiah masih sangat asli, pada sisi lainnya telah ada kunjungan wisatawan dalam jumlah kecil dan mereka masih leluasa dapat bertemu dan berkomunikasi serta berinteraksi dengan penduduk lokal. Karakteristik ini cukup untuk dijadikan alasan pengembangan sebuah kawasan menjadi sebuah destinasi atau daya tarik wisata.

\section{Strategi Pengembangan Ekowisata}

Berdasarkan kondisi eksisting yang diketahui dengan pengolongan faktor Internal dan Eksternal berdasarkan pembahasan sebelumnya, dapat diperoleh beberapa strategi melalui matrik SWOT. 
Tabel 2. Analisis SWOT Ekowisata Pegunungan di Gunung Ranai

\begin{tabular}{|c|c|c|}
\hline Faktor Internal & $\begin{array}{l}\text { Peluang (Opportunity) } \\
\text { 1. Terdapat Pusat Pelatihan yang bisa dimanfaatkan oleh } \\
\text { masyarakat dan wisatawan } \\
\text { 2. Kawasan gunung Ranai telah ditetapkan sebagai kawasan } \\
\text { lindung } \\
\text { 3. Adanya kelompok organisasi dan LSM yang siap mendukung } \\
\text { aktifitas wisatawan } \\
\text { 4. Telah tersedia akses menuju Natuna melalui laut dan udara } \\
\text { 5. Jarak lokasi gunung Ranai hanya } 4 \text { kilometer dari pusat kota } \\
\text { Ranai } \\
\text { 6. Lokasi yang sudah cukup dikenal dikalangan pecinta alam } \\
\text { dalam maupun luar daerah } \\
\text { 7. Adanya akses internet yang memadai. }\end{array}$ & $\begin{array}{l}\text { Ancaman (Threat) } \\
\text { 1. Terjadinya pemburuan hewan langka oleh masyaraka } \\
\text { setempat dan pendatang } \\
\text { 2. Kurangnya kesadaran masyarakat setempat terkai } \\
\text { pentingnya ekosistem hutan. } \\
\text { 3. Lemahnya pengawasan dinas terkait terhadap kondis } \\
\text { hutan. } \\
\text { 4. Kurangnya kesadaran para wisatawan untuk tidal } \\
\text { membuang sampah sembarangan di kawasan gunung. }\end{array}$ \\
\hline $\begin{array}{l}\text { Kekuatan (Strength) } \\
\text { 1. Memiliki bentang alam dan panorama yang } \\
\text { indah } \\
\text { 2. Komitmen pemerintah untuk mengembangkan } \\
\text { potensi wisata di Gunung Ranai } \\
\text { 3. Kondisi alam yang unik sebagai gunung } \\
\text { dengan hutan berawan dataran rendah } \\
\text { 4. Memiliki pos jaga dengan alat bantu } \\
\text { komunikasi yang memadai } \\
\text { 5. Tersedianya jalur pendakian } \\
\text { 6. Ketersediaan sumber air yang melimpah dan } \\
\text { langsung bisa dikonsumsi } \\
\text { 7. Terdapat beberapa jenis hewan langka } \\
\text { 8. Kondisi alam yang masih sangat alami } \\
\text { 9. Memiliki kawasan jelajah yang memadai }\end{array}$ & $\begin{array}{l}\text { 1. Merumuskan konsep ekowisata oleh pemerintah dengan } \\
\text { melibatkan kelompok-kelompok organisasi dan masyarakat } \\
\text { melalui LSM yang ada untuk melakukan pelatihan-pelatihan } \\
\text { terkait ekowisata pegunungan di pusat pelatihan yang ada. ( } \mathrm{S} \\
: 2 \text { dan } \mathrm{O}: 1,3 \text { ) } \\
\text { 2. Membuat jalur dan titik perhentian yang bisa dilewati oleh } \\
\text { para wisatawan secara detail yang menerangkan atraksi pada } \\
\text { setiap titik perhentian untuk disebar luaskan dengan } \\
\text { memanfaatkan jaringan kelompok organisasi dan LSM terkait } \\
\text { melalui media internet.( } \mathrm{S}: 2,5 \text { dan } \mathrm{O}: 3,6,7) \\
\text { 3. } \\
\text { yang unik, keberadaan satwa langka dan kealamiannya serta } \\
\text { pengamanan jalur yang ada agar wisatawan dari dalam } \\
\text { maupun luar daerah yang datang menjadi berkesan baik } \\
\text { secara langsung maupun melalui media internet }(\mathrm{S}: 3,4,7,8 \\
\text { dan } \mathrm{O}: 6,7)\end{array}$ & $\begin{array}{l}\text { Memaksimalkan fungsi pos jaga untul } \\
\text { 1. } \\
\text { meminimalisir perburuan hewan langka dan penebangar } \\
\text { hutan tak berizin. }(\mathrm{S}: 4 \text { dan } \mathrm{T}: 1,3,4) \\
\text { Pemerintah harus memanfaatkan is } \\
\text { pentingnya kealamian hutan dan keberlangsungan sumbe } \\
\text { air gunung di daerah kepulauan yang bersentuhar } \\
\text { langsung dengan kepentingan masyarakat dan wisatawat } \\
\text { sehingga menjadi nilai edukasi bagi masyarakat dar } \\
\text { wisatawan agar mau menjaga ekosistem hutan yang ada d } \\
\text { kawasan gunung Ranai. }(\mathrm{S}: 2,6,8 \text { dan } \mathrm{T}: 3,4,5)\end{array}$ \\
\hline
\end{tabular}




\begin{tabular}{|c|c|c|}
\hline Kelemahan (Weakness) & W-O & $\mathbf{W}-\mathbf{T}$ \\
\hline $\begin{array}{l}\text { 1. Fasilitas yang sudah tersedia dalam kondisi } \\
\text { tidak terawat } \\
\text { 2. Tidak adanya personil khusus (guide) untuk } \\
\text { menjadi pemandu bagi para wisatawan } \\
\text { 3. Kondisi area untuk campground yang kecil } \\
\text { dipuncak gunung. } \\
\text { 4. Pemerintah masih fokus pada wisata bahari di } \\
\text { Natuna. }\end{array}$ & $\begin{array}{l}\text { 1. Melakukan pelatihan di pusat pelatihan yang ada di Gunung } \\
\text { Ranai dengan melibatkan kelompok-kelompok organisasi } \\
\text { terkait untuk dijadikan tenaga pemandu bagi wisatawan } \\
\text { (Guide). (W :2 dan } \mathrm{O}: 1,3) \\
\text { 2. Melakukan pembuatan dan perawatan fasilitas yang tidak } \\
\text { merusak ekosistem yang ada sebab konsep ekowisata } \\
\text { merupakan wisata berbasis kelestarian lingkungan sehingga } \\
\text { status hutan sebagai kawasan lindung tetap terjaga. (W : } 1,3 \\
\text { dan } \mathrm{O}: 2 \text { ) }\end{array}$ & $\begin{array}{l}\text { 1. Menyediakan fasilitas kebersihan berupa tempat sampal } \\
\text { pada titik perhentian dan memberikan edukasi singka } \\
\text { oleh pemandu (Guide) kepada wisatawan sebelun } \\
\text { melakukan kegiatan agar wisatawan bisa membuan } \\
\text { sampah pada tempat yang telah disediakan dan lebih sada } \\
\text { lingkungan. (W: } 1,2 \text { dan } \mathrm{T}: 3,4 \text { ) } \\
\text { 2. Pemerintah harus memanfaatkan wisatawan yang ad: } \\
\text { untuk dikenalkan pada potensi ekowisata pegunungar } \\
\text { sehingga keterlibatan instansi terkait akan memperkua } \\
\text { pengawasan terhadap kelestarian satwa dan hutan alan } \\
\text { yang ada sebagai objek wisata di kawasan Gunung Ranai } \\
\text { (W: } 4 \text { dan } \mathrm{T}: 1,3 \text { ) }\end{array}$ \\
\hline
\end{tabular}


Berdasarkan hasil analisa tersebut, maka diperoleh beberapa poin terkait strategi pengembangan Ekowisata Pegunungan di Kawasan Gunung Ranai, Kabupaten Natuna, diantaranya adalah sebagai berikut :

1. Merumuskan konsep ekowisata oleh pemerintah dengan melibatkan kelompok-kelompok organisasi dan masyarakat melalui LSM yang ada untuk melakukan pelatihan-pelatihan terkait ekowisata pegunungan di pusat pelatihan yang ada.

2. Membuat jalur dan titik perhentian yang bisa dilewati oleh para wisatawan secara detail yang menerangkan atraksi pada setiap titik perhentian untuk disebar luaskan dengan memanfaatkan jaringan kelompok organisasi dan LSM terkait melalui media internet

3. Memfokuskan penyebarluasan informasi terkait kondisi alam yang unik, keberadaan satwa langka dan kealamiannya serta pengamanan jalur yang ada agar wisatawan dari dalam maupun luar daerah yang datang menjadi berkesan baik secara langsung maupun melalui media internet.

4. Memaksimalkan fungsi pos jaga untuk meminimalisir perburuan hewan langka dan penebangan hutan tak berizin.

5. Pemerintah harus memanfaatkan isu pentingnya kealamian hutan dan keberlangsungan sumber air gunung di daerah kepulauan yang bersentuhan langsung dengan kepentingan masyarakat dan wisatawan sehingga menjadi nilai edukasi bagi masyarakat dan wisatawan agar mau menjaga ekosistem hutan yang ada di kawasan Gunung Ranai.

6. Melakukan pelatihan di pusat pelatihan yang ada di Gunung Ranai dengan melibatkan kelompokkelompok organisasi terkait untuk dijadikan tenaga pemandu bagi wisatawan (Guide).

7. Melakukan pembuatan dan perawatan fasilitas yang tidak merusak ekosistem yang ada sebab konsep ekowisata merupakan wisata berbasis kelestarian lingkungan sehingga status hutan sebagai kawasan lindung tetap terjaga.

8. Menyediakan fasilitas kebersihan berupa tempat sampah pada titik perhentian dan memberikan edukasi singkat oleh pemandu (Guide) kepada wisatawan sebelum melakukan kegiatan agar wisatawan bisa membuang sampah pada tempat yang telah disediakan dan lebih sadar lingkungan.

Pemerintah harus memanfaatkan wisatawan yang ada untuk dikenalkan pada potensi ekowisata pegunungan sehingga keterlibatan instansi terkait akan memperkuat pengawasan terhadap kelestarian satwa dan hutan alam yang ada sebagai objek wisata di kawasan Gunung Ranai.

\section{KESIMPULAN}

Kondisi Atraksi yang terdapat di kawasan Gunung Ranai sangat beragam dan tergolong unik sehingga sangat berpotensi untuk dimanfaatkan sebagai objek wisata. Sedangkan amenitas dan aksesibilitas sudah cukup memadai untuk menunjang pengembangan ekowisata pegunungan tersebut. Peran pemerintah sangat diperlukan dalam pengembangan ekowisata pegunungan di kawasan Gunung Ranai. Adapun usaha itu harus melibatkan pihak-pihak terkait seperti organisasi-organisasi yang berkaitan dengan lingkungan serta instansi terkait. Disisi lain, upaya pemanfaatan potensi Sumber Daya Alam secara ramah dengan konsep ekowisata ini diperluan sebagai upaya untuk mempertahankan sumber air baku masyarakat setempat.

\section{UCAPAN TERIMAKASIH}

Penulis mengucapkan terimakasih kepada Allah SWT atas rahmat Nya, sehingga penelitian ini terlaksana dengan baik. Demikian pula atas dukungan semua pihak yang berkaitan dengan penelitian ini.

\section{DAFTAR PUSTAKA}

Butler, R. W. 1980. The Concept of Tourism Area Cycle of Evolution: Implications for the Management of Resources. The Canadian Geographer. Vol. 24: 5-12.

Maharadatunkamsi. 2000. Mamalia di Kecamatan Bunguran Timur Kabupaten Natuna.Dalam Inventarisasi Burung, Mamalia dan Herpetofauna Kabupaten Natuna. Halaman 22.

Riswandi. 2013. Strategi dan Program Pengembangan Pariwisata Bahari di Kabupaten Natuna. Thesis Magister di IPB Bogor : Tidak Diterbitkan. 